\title{
Milestone Report on Plutonium Immobilization Material Characterization: Milestone 1 Report - Initiate Design of Prototype Material Characterization System
}

\author{
C.J. Bannochie
}

June 1, 1999

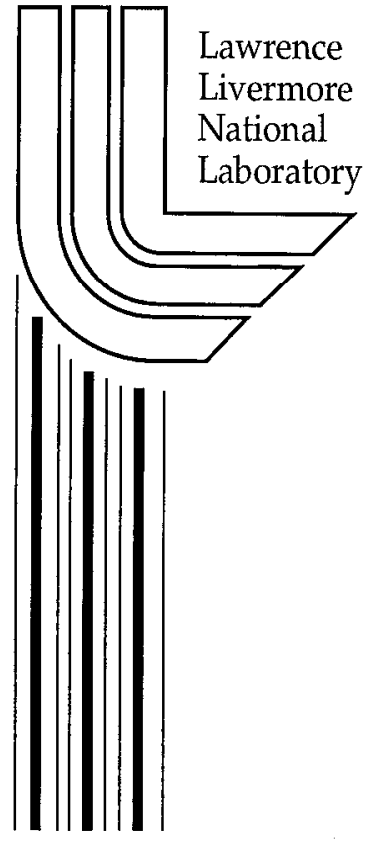




\section{DISCLAIMER}

This document was prepared as an account of work sponsored by an agency of the United States Government. Neither the United States Government nor the University of California nor any of their employees, makes any warranty, express or implied, or assumes any legal liability or responsibility for the accuracy, completeness, or usefulness of any information, apparatus, product, or process disclosed, or represents that its use would not infringe privately owned rights. Reference herein to any specific commercial product, process, or service by trade name, trademark, manufacturer, or otherwise, does not necessarily constitute or imply its endorsement, recommendation, or favoring by the United States Government or the University of California. The views and opinions of authors expressed herein do not necessarily state or reflect those of the United States Government or the University of California, and shall not be used for advertising or product endorsement purposes.

Work performed under the auspices of the U. S. Department of Energy by the University of California Lawrence Livermore National Laboratory under Contract W-7405-Eng-48.

This report has been reproduced

directly from the best available copy.

Available to DOE and DOE contractors from the

Office of Scientific and Technical Information

P.O. Box 62, Oak Ridge, TN 37831

Prices available from (423) 576-8401

http:/ / apollo.osti.gov/bridge/

Available to the public from the National Technical Information Service

U.S. Department of Commerce 5285 Port Royal Rd., Springfield, VA 22161

http://www.ntis.gov/

OR

Lawrence Livermore National Laboratory Technical Information Department's Digital Library http://www.llnl.gov/tid/Library.html 


\begin{abstract}
Milestone Report on
Plutonium Immobilization Material Characterization: Milestone 1

Report - Initiate Design of Prototype Material Characterization System (U)
\end{abstract}

Task 2.5.8

Milestone 1

June 1999

Christopher J. Bannochie, WSRC/LLNL 
Date: 28 June 1999

To: $\quad$ Mark Bronsom, LLNL

Karen Dodson, LLNL

From: C. J. Bannochie, WSRC/LLNL

\section{Plutonium Immobilization Task 2.5.8 Material Characterization: Milestone 1 Report - Initiate Design of Prototype Material Characterization System (U)}

\section{Background}

The objective of this task is to analyze impure oxide materials exiting from front-end processing prior to storage for feed blending. There are three goals to be accomplished with this task: reduce reblending (currently projected at $7 \%$ with an optimized ordering of the incoming material streams), determine if impure feed prep operations are performing adequately, and reduce plant operating costs by replacing wet prep elemental analyses whether conducted in the immobilization facility or in existing laboratories. An additional potential application is the analysis of blended oxide prior to first-stage $\mathrm{UO}_{2}$ and precursor addition.

The first step of the task was to define the performance requirements for the analyses. In general the selected analytical method needs to determine the elemental constituents in oxide feed with sufficient accuracy to flag problematic levels of impurities. Specifically, this entails the measurement of a variety of elements, including low atomic number $(Z)$ elements, in a heavy element matrix. The selected technique should minimize sample preparation, waste generation, operator/technician exposure, and delays to plant processing operations. Additionally, it is important to rapidly identify materials requiring further processing or blending.

The second step of the task was to survey potential analytical techniques and equipment. This was followed by an evaluation of the suitability of a given analytical technique against the performance requirements outlined above. The fourth step is the demonstration of the selected analytical technique with surrogate materials, to work out the general method parameters and representative "hot" oxide feed streams.

\section{Status}

The performance requirements for the analyses were defined. Specification limits on blended feed impurities, provided by Form Development, were converted from general classes (i.e. volatiles, stabilizers, etc.) to measurable chemical species or elemental concentrations, as shown in Table 1. The desired elements to be measured are $\mathrm{Al}, \mathrm{B}, \mathrm{Ba}$, $\mathrm{Ca}, \mathrm{Cr}, \mathrm{Cu}, \mathrm{Fe}, \mathrm{Ga}, \mathrm{K}, \mathrm{La}, \mathrm{Mg}, \mathrm{Mo}, \mathrm{Na}, \mathrm{Nd}, \mathrm{Ni}, \mathrm{P}, \mathrm{Pb}, \mathrm{Si}, \mathrm{Sn}, \mathrm{Ta}, \mathrm{W}, \mathrm{Zn}, \mathrm{F}$, and $\mathrm{Cl}$. 


\begin{tabular}{|c|c|c|}
\hline Element & Atomic Number $(\mathbf{Z})$ & $\begin{array}{c}\text { Concentration } \\
\text { (max. wt. \%) }\end{array}$ \\
\hline $\mathrm{B}$ & 5 & 0.6 \\
\hline $\mathrm{F}$ & 9 & 7.2 \\
\hline $\mathrm{Na}$ & 11 & 4.5 \\
\hline $\mathrm{Mg}$ & 12 & $4.7-6.0$ \\
\hline $\mathrm{Al}$ & 13 & 6.5 \\
\hline $\mathrm{Si}$ & 14 & 2.9 \\
\hline $\mathrm{P}$ & 15 & 1.1 \\
\hline $\mathrm{Cl}$ & 17 & $6.7-12.6$ \\
\hline $\mathrm{K}$ & 19 & 7.4 \\
\hline $\mathrm{Ca}$ & 20 & 7.1 \\
\hline $\mathrm{Cr}$ & 24 & 11.9 \\
\hline $\mathrm{Fe}$ & 26 & 12.6 \\
\hline $\mathrm{Ni}$ & 28 & 2.1 \\
\hline $\mathrm{Cu}$ & 29 & 12.2 \\
\hline $\mathrm{Zn}$ & 30 & 11.9 \\
\hline $\mathrm{Ga}$ & 31 & 15.3 \\
\hline $\mathrm{Mo}$ & 42 & 11.9 \\
\hline $\mathrm{Sn}$ & 50 & $25.2 \ddagger$ \\
\hline $\mathrm{Ba}$ & 56 & 18.2 \\
\hline $\mathrm{La}$ & 57 & $39.0 \ddagger$ \\
\hline $\mathrm{Nd}$ & 60 & $39.9 \ddagger$ \\
\hline $\mathrm{Ta}$ & 73 & 20.1 \\
\hline $\mathrm{W}$ & 74 & 20.6 \\
\hline $\mathrm{Pb}$ & 82 & $\mathrm{TBD}$ \\
\hline & & \\
\hline
\end{tabular}

Table 1: Preliminary specification limits on blended feed impurities, expressed as elemental weight percents. ${ }^{*}$ Values are based on data in Ref. 1 except as noted. $\$$ Values calculated from data contained in a January 99draft revision to Ref. 1. Note, any given incoming sample to material characterization may not contain any or all of these elemental contaminates.

In working through the second and third steps of the task, two potential analytical techniques were identified from a field of analytical techniques which had applicability to the measurement of a wide variety of elements: laser ablation inductively coupled plasma mass spectrometry (LA-ICP/MS) and x-ray fluorescence spectroscopy (XRF). The spectrum of techniques that were screened is shown in Table 2. A meeting was held with Lawrence Berkeley National Laboratory (LBNL) chemists to discuss the application of XRF to the analysis of immobilization feed streams. The first consideration was the fact that $\mathrm{Pu}$ and $\mathrm{U} \mathrm{M}$ - and $\mathrm{L}$-bands can mask low $\mathrm{Z}$ element $\mathrm{K}$-band emissions induced in $\mathrm{XRF}$ analyses. It would be necessary to count the background signal and subtract it from the $\mathrm{x}$-ray-induced signal. It would also be necessary to have extremely thin samples with small particles in order to eliminate matrix effects and thereby the need for standards. 


\begin{tabular}{|c|c|c|}
\hline Technique & Strengths & Weaknesses \\
\hline Infrared Spectroscopy (IR) & - none in this application & $\begin{array}{l}\text { - largely qualitative } \\
\text { - most applicable to organic and } \\
\text { organometallic structural studies }\end{array}$ \\
\hline $\begin{array}{l}\text { Atomic Absorption Spectroscopy } \\
\text { (AA) }\end{array}$ & - elemental technique & $\begin{array}{l}\text { - requires sample dissolution } \\
\text { - low elemental sensitivities } \\
\text { compared with ICP-MS, ICP-AES, } \\
\text { or XRF } \\
\text { - single element analysis } \\
\text { - flame in Pu hood or glovebox } \\
\end{array}$ \\
\hline $\begin{array}{l}\text { Nuclear Magnetic Resonance } \\
\text { Spectroscopy (NMR) }\end{array}$ & - none in this application & $\begin{array}{l}\text { - largely qualitative } \\
\text { - most applicable to organic and } \\
\text { organometallic structural studies } \\
\text { - requires liquid or dissolved samples }\end{array}$ \\
\hline $\begin{array}{l}\text { X-Ray Fluorescence Spectroscopy } \\
\text { (XRF) }\end{array}$ & $\begin{array}{l}\text { - elemental technique } \\
\text { - solid sample analyses } \\
\text { - non-destructive }\end{array}$ & $\begin{array}{l}\text { - light element quantification difficult } \\
\text { - U/Pu natural fluorescence interferes } \\
\text { - surface measurements only }\end{array}$ \\
\hline $\begin{array}{c}\text { X-Ray Diffraction Spectroscopy } \\
\text { (XRD) }\end{array}$ & $\begin{array}{l}\text { - elemental technique } \\
\text { - solid sample analyses } \\
\text { - crystalline information }\end{array}$ & $\begin{array}{l}\text { - powder pattern analyses difficult to } \\
\text { quantitate } \\
\text { - major elements only }\end{array}$ \\
\hline $\begin{array}{l}\text { Inductively Coupled Plasma - Mass } \\
\text { Spectroscopy } \\
\text { (ICP-MS) }\end{array}$ & $\begin{array}{l}\text { - elemental technique } \\
\text { - solid sample analyses possible with } \\
\text { Laser Ablation } \\
\text { - isotopic information }\end{array}$ & $\begin{array}{l}\text { - F not measured } \\
\text { - w/o Laser Ablation requires sample } \\
\text { dissolution } \\
\text { - isobaric interference }\end{array}$ \\
\hline $\begin{array}{c}\text { Inductively Coupled Plasma - } \\
\text { Atomic Emission Spectroscopy (ICP- } \\
\text { AES) }\end{array}$ & $\begin{array}{l}\text { - elemental technique } \\
\text { - solid sample analyses possible with } \\
\text { Laser Ablation }\end{array}$ & $\begin{array}{l}\text { - } \mathrm{F} \text { and } \mathrm{Cl} \text { not readily measurcd } \\
\text { - w/o Laser Ablation requires sample } \\
\text { dissolution } \\
\text { - U/Pu create spectral interference } \\
\text { requiring ion exchange removal of } \\
\text { actinides }\end{array}$ \\
\hline Ion Chromatography (IC) & $\begin{array}{l}\text { - elemental and molecular technique } \\
\text { - inorganic ions readily mcasurcd }\end{array}$ & $\begin{array}{l}\text { - requires sample dissolution } \\
\text { - limitcd dynamic range } \\
\text { - not applicable to anions and cations } \\
\text { simultaneously } \\
\text { - very slow } \\
\end{array}$ \\
\hline $\begin{array}{l}\text { High Performance Liquid } \\
\text { Chromatography (HPLC) }\end{array}$ & - none in this application & $\begin{array}{l}\text { - requires sample dissolution } \\
\text { - most applicable to organic } \\
\text { molecules and inorganic complexes } \\
\text { rcquiring purification and } \\
\text { quantitation } \\
\text { - slow } \\
\end{array}$ \\
\hline Neutron Activation Analysis (NAA) & - high sensitivity for certain elements & $\begin{array}{l}\text { - not applicable to all elements of } \\
\text { interest } \\
\text { - complex } \\
\text { - requires neutron source } \\
\end{array}$ \\
\hline Mossbauer Spectroscopy (MB) & - none in this application & $\begin{array}{l}\text { - molecular technique } \\
\text { - most applicable to structural } \\
\text { inorganic applications } \\
\end{array}$ \\
\hline Polarography & - high sensitivity & $\begin{array}{l}\text { - prone to interferences } \\
\text { - Hg waste } \\
\text { - limited to 2-3 elements at a time }\end{array}$ \\
\hline Coulometry & - accuracy & - not applicable to complex matrices \\
\hline Ion Selective Electrodes (ISE) & - high sensitivity & $\begin{array}{l}\text { - requires elemental separations } \\
\text { - not available for all elements of } \\
\text { interest } \\
\text { - low sensitivity }\end{array}$ \\
\hline
\end{tabular}

Table 2: Comparison of several standard analytical chemical techniques for applicability to the analysis of inorganic impurities in plutonium oxide powders. 
An additional conversation with a Savannah River Technology Center XRF expert revealed a strong opposition to the application of this technique for this matrix. It was felt that it would bc ncarly impossible to obtain meaningful data for the light elements. In order to have any chance of measuring the lighter elements a higher powered research grade instrument would be necessary. Based upon these considerations, there was neither a significant cost nor analytical advantage to XRF spectroscopy.

Of the remaining analytical techniques capable of providing a broad spectrum of analyses, inductively coupled plasma mass spectroscopy (ICP/MS) coupled with laser ablation (LA) has bcen most promising. By utilizing a laser for sample introduction, the major disadvantage of ICP spectroscopy, the need for solid sample dissolution in order to achieve nebulization, is eliminated. The laser suspends fine particles that are carried into the spectrometer via an argon gas stream. As long as the particles produced are less than approximately $1 \mu \mathrm{m}$, they are readily digested in the $8000^{\circ} \mathrm{C}$ plasma to form atoms and/or ions.

By climinating the need for sample digestion one can greatly increase the speed with which analytical results are produced on a given sample. Solid sample introduction also eliminates the potential for sample contamination during preparation for nebulization and significantly reduces mixed waste volumes. Additionally, there is a significant reduction in personnel exposure during sample analyses.

While LA-ICP/MS has significant advantages, it, nor any other single analytical tcchnique, is capable of providing all of the desired elements requiring measurement during immobilization operations. In particular, fluorine, due to its high electronegativity, is largely incapable of forming significant quantities of cations for mass spectrometry. For completeness, it should be noted that XRF spectroscopy is also a poor method to determine $\mathrm{F}$ in this matrix. Fortunately there are readily available methods for determining anions such as $F$ in solid samples, which can be utilized in the Plutonium Immobilization Facility (Ref.2).

LLNL does not have a LA-ICP/MS system. An existing ICP/MS system was considered for adaptation to solid sample introduction via laser ablation, but its software interface, sensitivity, and design made it less than an ideal choice for this application. Additionally, a system dedicated to solid sample introduction and dry plasma conditions, while not required is generally preferred for optimum sensitivity and readiness for sample analyses. Hence the current plan for the final step of the task is to procure the necessary analytical instrumentation and install it into room 1006 of the LLNL Plutonium Facility. A Hewlett-Packard (HP) ICP-MS order was ordered on June 18 with delivery anticipated around August 20, and a Merchantek Laser Ablation system was ordered on June 4, with an anticipated delivery ten weeks from receipt of order (August 13).

The equipment will be installed in a glovebox and hood combination. We are working closely with Merchantek to complete the design for the glovebox installation. A suitable hood designed for the HP 4500 instrument has been obtained from Savannah River. Currently B332 facility personnel are evaluating this design for any building specific 
modifications that may be required. Once this review is complete, the necessary equipment will be ordered and USQ and work review procedures initiated.

During the ordering and installation period we have outlined a series of experiments which need to be performed on cold surrogate samples in order to begin outlining an analytical procedure. These experiments will be run at LBNL in the laboratories of Dr. Rick Russo. The first experiment will involve looking at a simple $\mathrm{Cc}$ surrogate with In as an internal standard to ascertain the ablation characteristics of various particle sizes and mixing times. The use of binder materials will be assessed with the Ce surrogates. Both polyethylglycol and hydroxypropylmethylcellulose binders will be evaluated, since these are the two binders, currently in use for first stage immobilization development. Following these experiments, a series of elemental standards will be prepared with all the elements of interest at various concentrations starting with the standard surrogate formulation as well as $-50 \%,+50 \%$, and $+100 \%$ of the nominal elemental values. Since $\mathrm{Ce}$ is considerably lighter than $\mathrm{Pu}$, one surrogate pellet will be prepared with $\mathrm{Bi}$ substituted as the surrogate for $\mathrm{Pu}$ to evaluate the impact of a heavier matrix element on the ablation behavior. Additionally, since the eventual Pu samples will be highly colored and therefore may interact differently with laser light, one experiment will be done with $\mathrm{PtO}_{2}$, a black powder, as surrogate for the $\mathrm{CeO}_{2}$, to test the impact of colored oxides on the laser parameters.

\section{Conclusion}

In summary, the task is on track and procurement of the laser ablation ICP-MS instrumentation needed for this work is likely to be completed ahead of schedule.

\section{References}

1. Gray, L. W. et al. "Material Disposition Acceptance Specifications for the Plutonium Immobilization Project," Lawrence Livermore National Laboratory, PIP-98-047, August 1998.

2. Westinghouse Savannah River Company, "Fluorine, Chlorine, and Sulfate by Pyrohydrolysis (U)", Technical Reference Procedure Manual L3.19-10011, Rev. 1, March 15, 1999. 